\title{
János Jelenések könyve: a modern magyar környezeti irodalom születése
}

\section{Revelation to John: the birth of modern Hungarian environmental literature}

\author{
RÁCZ LAJOS
}

RÁCZ Lajos: egyetemi tanár, Szegedi Tudományegyetem, Juhász Gyula Pedagógusképző Kar; 6725 Szeged, Boldogasszony sgt. 6.; raczl@jgypk.szte.hu; https://orcid.org/0000-0002-2606-1616

KULCSSZAVAK: környezeti irodalom; éghajlatváltozás; kis jégkorszak

ABSZTRAKT: Térey János A Legkisebb Jégkorszak című verses regényében egy kisebbfajta éghajlati-környezeti apokalipszis történetének első másfél évét beszéli el. 2019 tavaszán előbb Izlandon, majd Itáliában is sorra kitörnek a vulkánok és elkezdődik egy globális léptékủ lehűlés, alkalmazkodásra kényszerítve a kortárs társadalmakat. A regény cselekménye Izlandon kezdődik, de a történet földrajzi fókusza valójában Budapest, és leginkább a Svábhegy, a legújabb kori magyar elit lakóhelye. A regénynek több főszereplője is van: Mátrai Ágoston, a későn házasodó karrierdiplomata, az ex-étteremtulajdonos újgazdag Labancz Győző, vagy Radák Zoltán miniszterelnök, akit a sámánista merénylők a soha meg nem valósult jelenkori magyar felvirágzás mártírjává tesznek. Rövid írásomban annak a bizonyítására tettem kísérletet, hogy a természeti környezet, esetünkben az éghajlatváltozás ugyanolyan aktív és meghatározó szereplője a cselekmény alakulásának, mint a regény szereplői. A szógyakoriság vizsgálatával és tartalomelemzéssel azt kíséreltem meg bizonyítani, hogy Térey János verses regénye illeszkedik abba az 1980-as években induló nemzetközi irodalmi áramlatba, amelyet környezeti irodalomnak neveznek. A környezeti irodalom koncepciójának első kidolgozója, Cheryll Burgess Glotfelty a természeti környezetre nem az emberi cselekvést elszenvedő statikus háttérként tekintett, hanem mint a holisztikusan szemlélhető és interaktív módon működő humán ökoszisztéma egyik főszereplőjére. Ugyanakkor Térey folytat egy, a magyar irodalomban hosszú idő óta létező hagyományt is a természeti környezethez való viszony értelmezését illetően. Ennek a környezeti irodalmi tradíciónak fontos mérföldkövei voltak Petőfi Sándor Tisza című költeménye, amely a folyószabályozások korának optimista programverse, vagy Madách Imre Az ember tragédiájában az Eszkimó szín víziója, amely elképesztően és korszerűen pesszimista jövőkép volt a 19. század derekán. Következtetésem szerint Térey János verses regénye tekinthető a (poszt)modern magyar környezeti irodalom első, remélhetően úttörő vállalkozásának.

Lajos RÁCZ: professor, Juhász Gyula Faculty of Education, University of Szeged; Boldogasszony sgt. 6., H-6725 Szeged, Hungary; raczl@jgypk.szte.hu; https://orcid.org/0000-0002-2606-1616

KEYWORDS: environmental literature; climate change; Little Ice Age

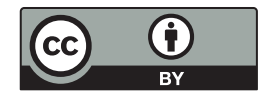


ABSTRACT: János Térey's poem-novel, "The Smallest Ice Age", recounts the first one and a half years history of a minor climatic-environmental apocalypse. In the spring of 2019, volcanoes erupt, first in Iceland, later in Italy and then a global scale cooling begins, forcing contemporary societies into adaptation. The plot starts on Iceland, but the geographical focus is Budapest, and mostly Svábhegy in fact, the residential area of the contemporary Hungarian elite. The novel has more main characters, like Ágoston Mátrai, the late married career diplomat, the ex-restaurant owner upstart Gyözó Labancz, or the prime minister Zoltán Radák, who the shamanist assassins made the martyr of the never fulfilled contemporary Hungarian prosperity.

In my short study, I try to demonstrate and verify that climate change and the physical environment are just as active and determining characteristics of the plot as the human characters. With the method of word frequency and the content analysis, I tried to prove that the poem fits into an international literary current, called environmental literature, launched in the 1980s. Cheryll Burgess Glotfelty, the elaborator of the concept, did not consider the physical environment as the static background enduring human action, but as one of the main agents of the human ecosystem, which latter, in turn, can be contemplated holistically and function in an interactive manner.

Térey, however, also follows a tradition existing for a long time in Hungarian literature, that is, the interpretation of relationships to the physical environment. The Hungarian environmental-literary tradition had important milestones, like the poem of Sándor Petófi's Tisza, one of the optimistic program poems of the age of water regulation, or the pessimistic vision of the Eskimo scene in Imre Madách's Tragedy of Man, an astonishingly contemporary vision from the 19th century. I consider János Térey's poem novel as the first representation of the (post)modern Hungarian environmental literature, which I hope will have many followers.

Magyarország, 2019 tavasza, az ország miniszterelnöke, a szociáldemokrata Radák Zoltán (akinek érdemes visszafelé is elolvasni a vezetéknevét) a jobbközéppel kötött nagykoalíció támogatásával megnyerte a 2018-as választásokat. A miniszterelnök

\section{(...) ideálprogramja az elhajlásoktól mentes}

Kultúrköztársaság, amelyben vezetö

Értelmiségiek, tudósok, közgazdászok a miniszterek.

Tehát - eltérően a múltbeli gyakorlattól -

Nem pártmameluk senkiháziak. (Térey 2015, 121.)

Minden jel szerint véget ért az ezeréves történelmi pechszéria, és a 35 éves, selyemfényü Aston Martinját vezető sármos miniszterelnök példás gyorsasággal átformálta a magyar közéletet, egy év kormányzás után úgy látja:

A nyugati fejlödés fóáramába visszatértünk.

A botránybaloldal és a vezérdemokrácia után

Visszaadtam a nemzetnek az öntudatát. (Térey 2015, 390.)

De az ezeréves történelmi pechszéria nem ért véget, és 2019 tavaszán előbb Izlandon, majd az Itáliai-félszigeten egymást követően, egymás hatását felerősítve kitörnek a tüzhányók, amelynek következtében globális lehűlés kezdődik. Térey János verses regénye ennek a jégkorszaknak az első másfél évét beszéli el, szereplői pedig legfőképpen a magyar (politikai, gazdasági és tudományos) elit tagjai.

A Legkisebb Jégkorszak 2015-ös megjelenése óta nagyszámú kritika jelent meg (Bencsik 2015; Földényi 2015; Pogrányi 2016; Radnóti 2015; Varga 2016; Zsolnai 2016), ám ezek az írások érdemben nem foglalkoztak a verses regény 
környezeti vonatkozásaival. Varga Melinda (2016) ismertetésében úgy fogalmaz, hogy „A költő a környezeti katasztrófát keretként használja a jelenlegi magyar társadalmi helyzetkép bemutatására." Radnóti Sándor (2015) szerint Térey „Nagy költői energiákat mozgósított a hó, a fagy, a hosszú tél ábrázolására. Nyilvánvaló, hogy ez metaforikusan is értendő, amennyiben Magyarország - és egész Európa - befagyott. De a lírai jelkép széles epikus megalapozást kap, hatalmas tájleírásokat, a természeti erők hatásos fölidézését és okszerű magyarázatát." Azt gondolom, a jeles irodalmárok a természeti környezet regénybeli szerepének értelmezésében tévednek. Meggyőződésem szerint A Legkisebb Jégkorszak aktív szereplője a természeti környezet, amely nemcsak meghatározza a cselekmény irányát, de folyamatosan mozgásban is marad, alakítja a történet/történelem menetét, beavatkozik a szereplők életébe, meghatározza a Földön, esetünkben és általában véve Európában, különösen Magyarországon, a leginkább pedig a Svábhegyen az ember által tartósan birtokba vehető és élhető világnak a határait, az antroposzféra kiterjedését és belső struktúráját.

A természeti környezet az irodalom régi színtere és szereplője: a Gilgameseposz egyik föszereplője, Enkidu a vadonból érkezett Uruk városába, Odüsszeusz egy évtizedig bolyongott a tengeren, keresve az Ithakába vezető utat, az ószövetségi hagyomány szerint pedig az emberek büneit Isten rendre természeti katasztrófákkal büntetette. A természeti környezet irodalmi ábrázolása különösen alkalmas a kódolt kommunikációra az író és az olvasó között. Nem véletlen, hogy a szovjet-orosz irodalomban a környezeti konfliktusok jelentették az első lehetőséget a diktatórikus rendszer elleni tiltakozásra. ${ }^{1}$ A természeti környezet irodalmi megjelenésének értelmezésére irányuló szándék ugyanakkor a magyar irodalomtörténetben (legjobb tudomásom szerint) még nem jelent meg. Mentségére szolgál a honi irodalomkritikának, hogy globálisan is viszonylag új gondolati áramlatról van szó. A környezeti vagy ökológiai irodalomról (environmental literature vagy literary ecology) való gondolkodás, az ökokritika (ecocritics) az 1980-as évek második felében jelent meg az Egyesült Államok akadémiai-egyetemi világában (Glotfelty, Fromm 1996). Az alapító anya Cheryll Burgess Glotfelty volt, aki az amerikai irodalomban Henry David Thoreau munkásságától Edward Abbey színre lépéséig azt vizsgálta, milyen módon jelent meg a természeti környezet az amerikai és a világirodalomban. ${ }^{2}$ Annak, hogy a természet az amerikai irodalomkritika fontos kérdésévé vált, részint sajátosan amerikai, részint pedig globális okai voltak. A 19. századi alapítású ökológia eredendően a biológia szubdiszciplinájaként jelent meg, ${ }^{3}$ amelynek művelői az ökoszisztémákban élő állati és növényi életközösségek belső viszonyait vizsgálták, illetve kapcsolatukat a fizikai környezetükkel. Az ökológiai gondolkodás eszkalációját egy amerikai tengerbiológus, ökológus és újságíró, Rachel Carson 1962-ben megjelent könyve, a Silent Spring indította el (magyar nyelven: Carson 1994). Rachel Carson az amerikai tudományos élet meghatározó tradícióját követte, amikor a "general reader" (az átlagos olvasó) számára is közérthető módon írt a környezetszennyezés ökológiai, egészségügyi és társadalmi hatásairól. Az Egyesült 
Államokban, ahol az amerikai nemzet születése szorosan egybekapcsolódott a természeti környezet átalakításával, ez a gondolat rendkívüli hatást gyakorolt a hétköznapi gondolkodásra, a politikai életre és a tudományos diskurzusra egyaránt. Abban, hogy az 1960-as évektől az ökológiai problémák globális kérdéssé váltak, fontos szerepet játszott az is, hogy a második világháború után kibontakozó példátlan gazdasági növekedés következtében az emberiség olyan erőforrások mozgósítására vált képessé, amekkorával korábban csak a természeti erők rendelkeztek. Az ökológiai gondolkodás globalizációja az 1960-as évek végétől elvezetett az ökológiai mozgalmak színre lépéséhez, a környezetpolitikai gondolkodás és intézményrendszer kialakulásához, ráadásul arra sarkalta a legkülönbözőbb tudományok művelőit, hogy reflektáljanak az ember és a természeti környezet közötti új viszonyrendszerre és az ebből származó konfliktusokra. Az 1970-80-as években jelent meg a környezettörténet, a környezetfilozófia, a környezetszociológia, a környezet-gazdaságtan, hogy csak a legfontosabbakat említsük. Fontos szemléletbeni változás volt, hogy az új tudományterületek művelői a természeti környezetet az emberi társadalommal egyenrangú dinamikus rendszerként értelmezték. Cheryll Burgess Glotfelty fellépésének ${ }^{4}$ és az ökokritika megjelenésének ez volt a társadalmi és tudománytörténeti háttere. A környezeti irodalommal foglalkozó amerikai kutatók 1992-ben létrehozták az Association for the Study of Literature and Environment-et (ASLE: www.asle.org), amelynek a hozzáférhető nyilvántartás szerint jelenleg az Egyesült Államokban mintegy 900 tagja van. A társaság megjelentett egy folyóiratot is Interdisciplinary Studies in Literature and the Environment (ISLE: www.asle.org/research-write/ isle-journal/) címen. Az ökokritika tevékenységi területének meghatározását illetően nincs teljes konszenzus a szakirodalomban, de alapvetően háromféle felfogás erősödött meg. Az ökokritika művelőinek egy csoportja úgy tartja, hogy elsőrendűen azt kell vizsgálni, a természeti környezet miként jelenik meg az irodalmi szövegekben, a másik felfogás szerint az ember-természet együttélés során felmerülő morális kérdésekre kell koncentrálni, végül a környezeti aktivista irányultságú irodalmárok szerint annak az elemzése a legfontosabb, hogy a környezeti problémák miként jelennek meg az irodalomban. Az ökokritika az amerikai irodalomtudomány nem meghatározó, de fontos irányzata, amely kiterjedt hálózatot hozott létre az akadémiai-egyetemi világban.

A természeti környezet ábrázolása a magyar irodalom minden korszakában jelen volt, az ábrázolás kontextusát ugyanakkor jobbára a korszellem, a modern világban legfőképpen a tudományos gondolkodás határozta meg. Petőfi Sándor Tisza címü költeménye (amennyiben eltekintünk a „pór menyecske” költőre gyakorolt hipnotikus hatásától) a folyószabályozások korának optimista programverse, amelynek különösen hatásos a paradox argumentációja. Madách Imre Az ember tragédiájában az Eszkimó szín víziója elképesztően és korszerüen pesszimista. Madách 1860-ban fejezte be a Tragédiát, és az Eszkimó színben Lucifer pontosan felmondja azokat a tudományos téziseket, amelyek az amerikai George Perkins Marsh Man and Nature címü, 1864-ben megjelent nagy je- 
lentőségű tudományos szintézisének a konklúziói. Marsh szerint az ember kettős természetü, természeti lény és kultúrahordozó egyszerre, a környezeti konfliktusok jó részét pedig ennek a kettős természetnek a konfliktusa, illetve negligálása okozza. Lucifer interpretációjában: „Mindég az állat első bennetek, / És csak midőn ezt el birád csitítni, / Eszmél az ember, hogy nagy-gőgösen / Megvesse azt, mi első lényege” (Madách 1971, 157.). Marsh víziója szerint „Az emberi beavatkozás a Föld felszínét oly mértékben elpusztítja és tönkreteszi, hogy az csaknem a Holdhoz válik hasonlóvá" (Marsh 1965, 42.). Madách sem kevésbé pesszimista, a tizennegyedik szín vigasztalan képe: „Hóval és jéggel borított hegyes, fátalan vidék. A nap mint veres, sugártalan golyó áll ködfoszlányok között" (Madách 1971, 153.). Lucifer pedig így invitálja a pusztulás határán egyensúlyozó emberiség világába Ádámot: „E vérgolyó napod. / Lábunk alatt a föld egyenlitője. / A tudomány nem győzött végzetén." (Madách 1971, 154.). Amihez Térey János víziója nagyon hasonlatos: „nap fénykorongja, mint egy rézvörös / Krampuszarc, ringott az égen" (Térey 2015, 246.).

Térey János könyve, ami a tudományos kontextus aktualitását illeti, méltó párja Petőfi tájverseinek és Madách Az ember tragédiájának. A tétel, amelynek a bizonyítására kísérletet teszek az, hogy Térey a természeti környezetet aktív és tevékeny szereplőként kezeli verses regényében, ráadásul egy természeti katasztrófa tesztjét is lefuttatja számunkra, akik az előtörténet gyanakvó részesei vagyunk.

A bizonyítás első lépéseként szógyakorisági vizsgálatot végeztem a regény szövegén, ${ }^{5}$ azokra a szavakra szükítve a kört, amelyek a természeti környezet öntörvényü működése szempontjából relevánsak és nagyobb számban fordultak elő a szövegben. A kiválasztott szavak a következőek voltak: vulkán (41 említés), fagy (59), jég (140), hó (302) és tél (62). A regény szövegének olvasása során azt tapasztaltam, hogy valamilyen környezeti változás vagy körülmény rendre beleavatkozott a történet menetébe, a környezeti szereplő folyamatosan játékban maradt a cselekmény teljes hosszában. Ilyen módon a természeti környezetet tekinthetjük a regény egyik föszereplőjének, ami azért sem zavaró, mert Térey regényének több főszereplője is van. Ezek a főszereplők korunk hősei: Mátrai Ágoston, a későn házasodó karrierdiplomata, az ex-étteremtulajdonos újgazdag Labancz Győző, akinek a rosszullétei időalagutakat nyitnak a 20. századi magyar történelem irányába, vagy éppen Radák Zoltán miniszterelnök, akit a sámánista merénylők a soha meg nem valósult modern kori magyar felvirágzás mártírjává tesznek. Van egy fontos mellékszereplője is a regénynek, akiről mindenképpen említést kell tennem: Dolina Iván főmeteorológus, aki a televízió egyenes adásában kelt a tudományos megismerés védelmére:

„Maga meg mit idegeskedik?", fordult

Az asztrológushoz, aki fölugrott és nekiesett Dolinának,

Szabályosan összeverekedtek a képernyőn. (Térey 2015, 36.)

Ha valaki elolvasta a kötet végi köszönetnyilvánítást, akkor nem volt nehéz beazonosítani, hogy Dolina Iván valójában Dunkel Zoltán alteregója, aki korábban az Országos Meteorológiai Szolgálat főigazgatója és a regény szaklektora 
is volt. Ritka kegyelem a természettudományok művelői számára a regényhőssé válás, Dunkel Zoltán számára megadatott, amiért őszintén irigylem.

De nézzük a bizonyítást! Az 1. ábra az éghajlatváltozás szempontjából releváns öt kifejezés időbeni eloszlását mutatja a szövegtestben. Első látásra is szembetűnő, hogy a 609 oldalas verses regényben a klímaváltozás valamely jellemzője folyamatosan jelen van, gyakran többszöri említéssel és többféle vonatkozásban.

Amint azt a vulkánok említési gyakoriságát ábrázoló 2. ábra mutatja, a vulkánkitörések indítják el a legkisebb jégkorszakot, ${ }^{6}$ előbb az izlandiak, amelyekhez némi késéssel csatlakoznak az itáliai vulkánok is, felforgatva a kortársak életének a földrajzi-éghajlati kereteit. Dicséretes módon Térey János nemcsak szakértőt kért fel, de tanulmányozandó a vulkánok müködését, elutazott Izlandra is. A szakirodalmi ismereteknek és a terepen gyüjtött tapasztalatoknak köszönhetően szakmai szempontból is igen meggyőző az izlandi vulkánok kitörésének bemutatása. Ugyanakkor meglepő kihívás lehet a dokumentumfilmek által kondicionált olvasók számára a regény szövege alapján létrehozni a belső mozit. A fizikai világ részletes szöveges interpretációja bizonyosan nem fog kiveszni az irodalomból, de a modern prózában nem számít széles körben használt megoldásnak.

1. ábra: Az éghajlati változásra utaló öt kifejezés (vulkán, jég, hó, fagy és tél) említéseinek eloszlása Térey János A Legkisebb Jégkorszak címủ verses regényének szövegében The distribution of five expressions implying climatic change (volcano, ice, snow, frost, and winter) in the text of the poem-novel of The Smallest Ice Age by János Térey

$\bullet$ vulkán $\square$ jég $\Delta$ hó $\times$ fagy $\times$ tél

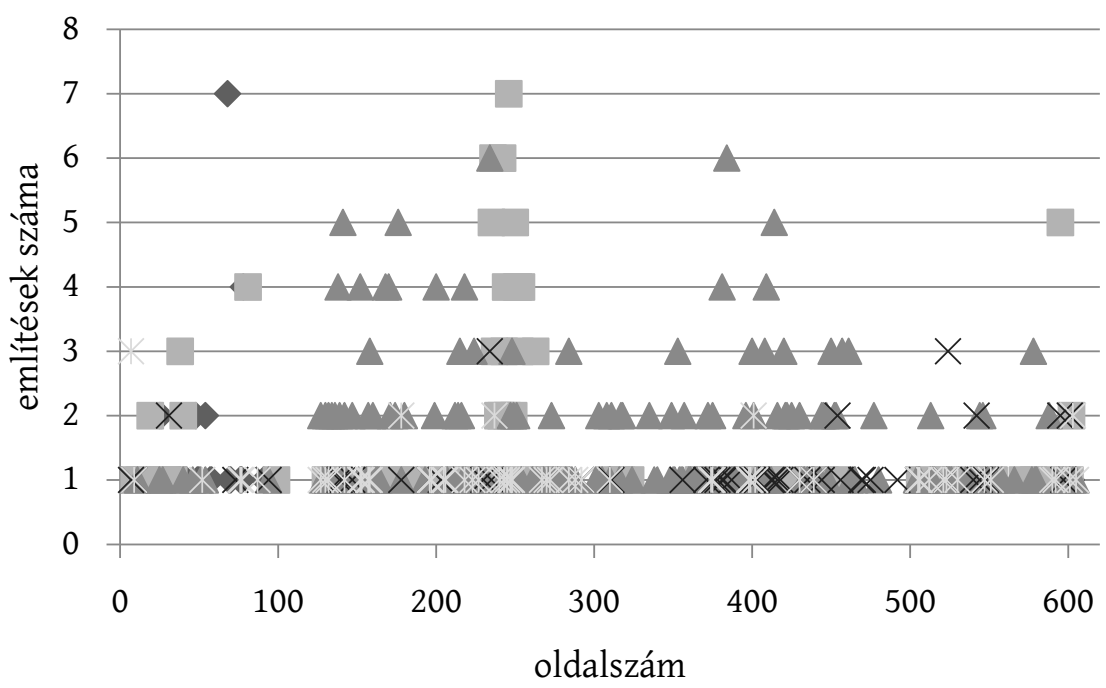


2. ábra: A vulkán említésének eloszlása Térey János A Legkisebb Jégkorszak című verses regényének szövegében

The distribution of references to the volcano in the text of the poem-novel of The Smallest Ice Age by János Térey

vulkán

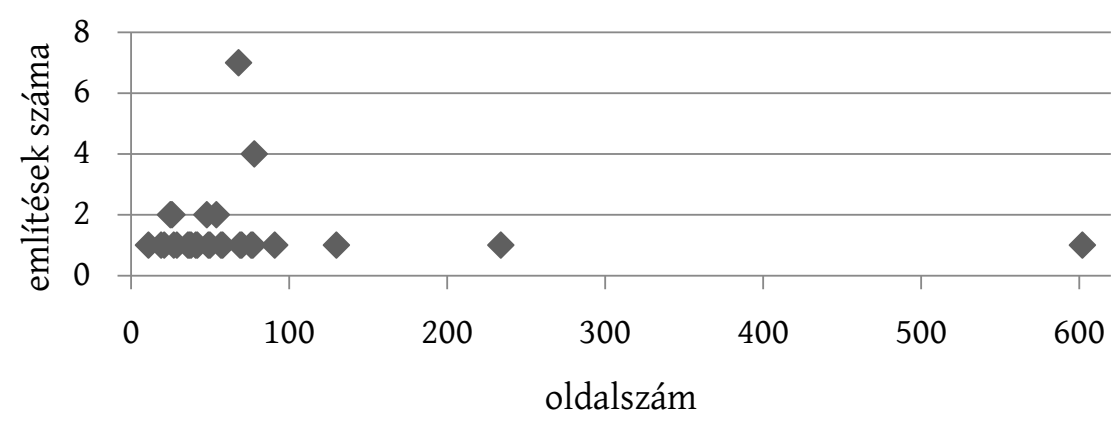

A Kárpát-medence geológiai szerkezetének vulkanológiai szempontból fontos sajátossága a Balaton-felvidéktől a Székelyföldig húzódó belső-kárpáti vulkáni ív, amelynek legkeletibb tagja, a Hargita néhány tízezer éve még aktív lehetett. ${ }^{7}$ De Térey János életre keltette a Balaton-felvidék hárommillió éves tüzhányóit is A magyar vulkándalban, amelyet előadásra javaslok a földrajzos szakesteken szabad művészi interpretációban:

Levendulás Tihanyunkban

Lefegyverzőn kedves arcú

Szürkemarhák kémlelik

Az elektromos kerités

Mögül, ahogy fölfortyan és

Újra buzog a mágikus

Erömezö! Olvadt kőzet

Maradéka nyomul egyre

Fölfelé csak fölfelé!

Perzselt füvü Tihanyunkban

Félelemtöl torz pofájú,

Eszeveszett szürkemarhák

Döntik le karámjukat. (Térey 2015, 69.)

A vulkánkitörések tartós klímaváltozást indítanak el, az időjárás egyre hidegebbre fordul, és elkezdődik a legkisebb jégkorszak, nem minden előzmény nélkül. Önmagában véve a jégkorszak egy földtörténeti terminus, amely azokat az időszakokat jelöli, amikor a Föld pólusait jégsapka borította. Ha ezt a meghatározást elfogadjuk, akkor jelenleg is egy jégkorszakban élünk, amely a Föld történetének nem gyakori állapota, a teljes, geológiai eszközökkel megismerhető időtartam alig több mint tíz százalékát teszi ki. A kis jégkorszak fogalma a 
20. század derekán jelent meg a szakirodalomban, és manapság a 14. században kezdődő és a 19/20. fordulójáig tartó globális lehülést értik rajta (részletesebben lásd Rácz 2016). A „kis” jelző a két és fél millió éves pleisztocén „nagy” jégkorszakától való megkülönböztetést szolgálja, illetve arra utal, hogy a klímaváltozás geológiai léptékben mérsékelt erejü volt, hiszen a pleisztocén jégkorszak $2-3^{\circ} \mathrm{C}$-os lehűlésével szemben a kis jégkorszak idején még a legkritikusabb években sem haladta meg a lehülés éves hemiszférikus átlagban a 0,6-0,8 ${ }^{\circ} \mathrm{C}$-ot. A Térey János által teremtett legkisebb jégkorszak ebbe a glaciológiai kontextusba illeszkedik, és jégkorszakhoz illően hidegnek kell lennie. A hideg nagyságáról leggyakrabban a fagyesemények tanúskodnak a regény szövegében (3. ábra).

Az, hogy a Duna vagy az Adria Dubrovniknál befagy, történelmi léptékben nem számít kivételes eseménynek, hiszen a nagyobbik kis jégkorszak hidegebb periódusaiban a késő középkor és az újkor idején erre számos alkalommal sor került. ${ }^{8} \mathrm{~A}-20^{\circ} \mathrm{C}$-os fagy rendkívüli ugyan, de minden téli hónapban lehet ilyen minimumokkal számolni, esetenként még november végén és március elején is. ${ }^{9}$ A regény „proxy” információi azonban arra utalnak, hogy már nem csak a szokásos szélsőértékek ismétlődtek a szokottnál gyakrabban, hiszen:

Megálltak a kapualjban, és haboztak.

Egyelöre nem merték kidugni az orrukat:

Féltek, nehogy leborotválja a szél.

„Megint olyan hideg van, hogy belefagy

Az ember szájába a nyál. (Térey 2015, 378.)

Máshol kislányok fújtak a szabadban szappanbuborékokat,

Amelyek azonnal tündöklö gömbökké fagytak. (Térey 2015, 413.)

A lábosból kiöntött, forrásban levő víz

Még a levegőben, földet érés előtt jéggé dermedt. (Térey 2015, 412.)

3. ábra: A fagy említésének eloszlása Térey János A Legkisebb Jégkorszak címu” verses regényének szövegében

The distribution of references to the frost events in the text of the poem-novel of The Smallest Ice Age by János Térey

fagy

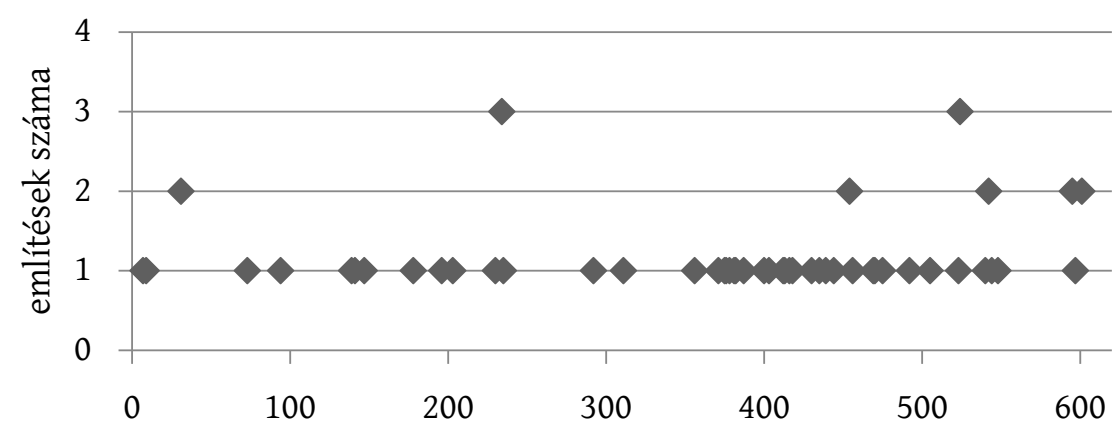


A szélsőségesre forduló időjárás egyre magasabbra emelte a túlélési küszöböt a budapesti ökoszisztéma minden élőlénye számára:

Látta, fagyott verebek és szarkák

Teteme hever a völgy legalján. Több száz vagy ezer. (Térey 2015, 382.)

Az itéletidö átvonulása százas

Nagyságrendben emberéletet követelt

(Autóbaleset, gyorshajtás, némi sebességmámor,

Jeges út vagy a gumik gyalázatos állapota...).

Hajléktalanok fagytak halálra, haltak éhen; (Térey 2015, 387.)

A fagyos időjárásnak ugyanakkor figyelemreméltó geopolitikai következményei is mutatkoztak:

Befagyott a magyarság,

$S$ ami különösen fájt neki:

Egybefagyott féltékeny szomszédaival;

Osztozva szlovén, horvát és osztrák,

Sőt szlovák, szerb, román és ukrán

Társaival, mi több: majdnem egész

Európával a közös hóhalálozásban...

Unikális sorsa közös mederbe került. (Térey 2015, 524.)

$\mathrm{Az}$ erősödő lehülés következtében egyre nagyobb vízfelszínek váltottak halmazállapotot, a folyamat különösen felerősödött a regény második harmadának elején, amikor 60 oldalon belül 75 alkalommal szerepelt valamilyen klimatikus kontextusban a jég kifejezés (4. ábra).

Novemberben, pár emberöltőnyi szünet után

Újrajéghíd keletkezett a Dunán. (Térey 2015, 241.)

Ha egészen pontosak akarunk lenni, akkor 56 év telt el, hiszen 2019 novemberét megelőzően a Duna utoljára 1963-ban fagyott át. A Duna szabályozása

4. ábra: A jég említésének eloszlása Térey János A Legkisebb Jégkorszak című verses regényének szövegében

The distribution of references to the ice events in the text of the poem-novel of The Smallest Ice Age by János Térey
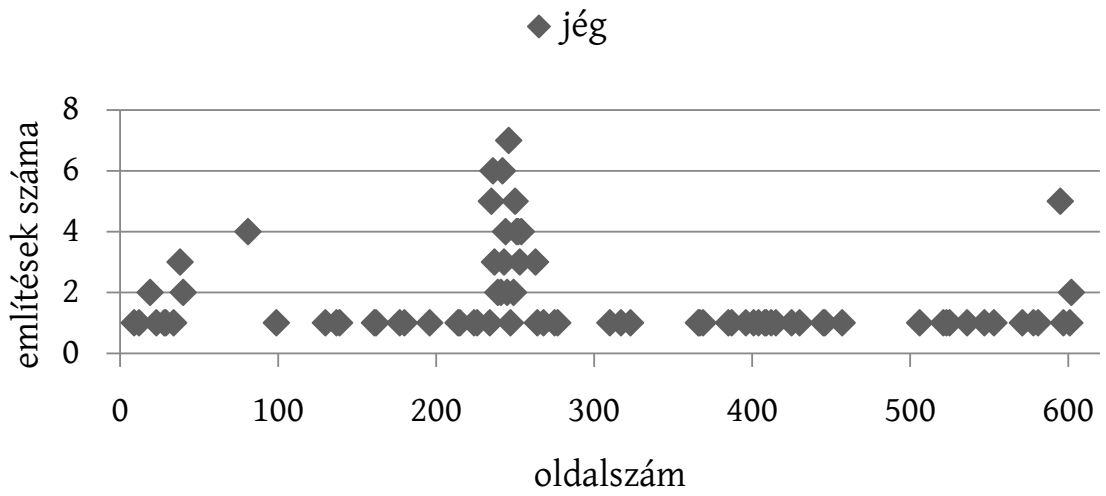
előtt, a kis jégkorszak idején a folyó zajlása általános jelenség volt, a 19. századi megfigyelések szerint 28 esztendőből egyben maradt csak ki, a befagyásra pedig átlagban minden második-harmadik évben sor került (részletesebben lásd Lászlóffy 1934, Tőry 1952). A Duna-hidak megépüléséig a jéghíd a Duna két partja közötti közlekedés fontos segítője volt, a jég állékonyságát szalmával javították, a közlekedést pedig a biztonságos jégsáv éjszakai kivilágításával. A 21. század élménytársadalma számára azonban a befagyott Duna már nem létfontosságú közlekedési lehetőség (arra ott vannak a hidak, vagy a jégtörő hajók), hanem lehetőség az extrém sportok egy szokatlan válfajának gyakorlásához, a mesterséges rianás keltéséhez a befagyott Duna jegén. Labancz „Győző életének bűnös öröme / A jéggel való szenvedélyes játék volt." (Térey 2015, 250.).

Győző lélegzet-visszafojtva figyelte:

A csákányt a jégbe vágva

Egy több másodpercig tartó,

Távolba szaladó repedéshang volt hallható,

Utána azonnal hajszálvékony

Fekete csikjelent meg a jégen.

És egy gyönyörü, több kilométerre elnyúló,

Parttal párhuzamos rianássá tágult.

Egészen elképesztó látvány volt,

Ahogy a több négyzetkilométeres jégtábla

Távolodik attól a táblától,

Amelyen jégbe gyökerezett lábbal Győző áll.

Megpróbált fölállni, de az ingójégen

Tompa puffanással elöreesett. (Térey 2015, 253-254.)

Szibéria Magyarországra költözését nem volt könnyű a budapestieknek sem elviselni, sem pedig feldolgozni, persze a trauma nem előzmények nélküli, így a lelki kárenyhítés eszközei is adottak voltak.

A Legkisebb Jégkorszak legelső telén

Budapest lakossága ámokfutva élt;

S hétvégén diszkotékákat látogatott,

Örjöngeni. Nem félni. És felejteni. (Térey 2015, 521.)

A Kárpát-medencében a csapadék mennyiségének, időbeni eloszlásának és halmazállapotának változása sokkal megbízhatóbb és erőteljesebb indikátora az éghajlatváltozásnak, mint a hőmérsékletváltozás. Némi egyszerüsítéssel felmelegedés idején csökken a csapadék mennyisége, a nyári félév egyre szárazabbá válik, télen pedig a csapadék egyre inkább eső formájában hullik. Lehűlés alkalmával nő a csapadék mennyisége, a téli csapadék pedig növekvő mértékben hó. A legkisebb jégkorszak idején a budapestiek úgy érezték magukat, „Mintha egy alsó-ausztriai falucskába csöppentek volna” (Térey 2015, 215.), ahol „Esett megint a hó oroszos nekibuzdulással” (Térey 2015, 284.). Amennyiben a tartós havazás Magyarországon szóba kerül, akkor földrajzilag ez az asszociációs kör hívódik be. Oroszországról kézenfekvő Szibériára asszociálni, Ausztria inkább a 
5. ábra: A hó említésének eloszlása Térey János A Legkisebb Jégkorszak című verses regényének szövegében

The distribution of references to the snow in the text of the poem-novel of The Smallest Ice Age by János Térey
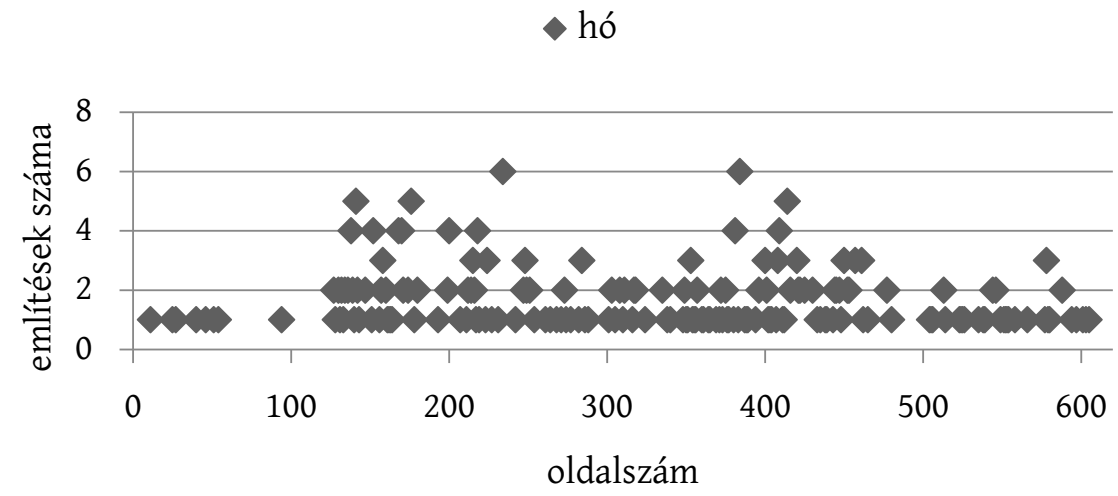

wellness vonatkozásában jut eszünkbe, bár történetileg azért Kufstein árnyalja ezt a képet.

A legkisebb jégkorszak magyarországi történeteiben a legnagyobb gyakorisággal megjelenő környezeti tényező a hó (5. ábra), amely megnehezíti a közlekedést, előretolja a természeti környezet határait, az embereket pedig beszorítja az épített környezet füthető részébe, ahol azonban „lassan falon át is érezni a hószagot" (Térey 2015, 168.). A vaddisznók pedig, az emberek világának visszavonulását követve és a hideg által szorongatva megjelentek a budai utcákon. ${ }^{10} \mathrm{~A}$ túlélés, akár egy háborúban, személyes üggyé vált:

A járókelók éjjel elképedve bámultak egymásra:

Az utcán valóságos hóhegyek

Tornyosultak. És virradatra megszünt

Az átjárás a közvetlen szomszédok között is. (Térey 2015, 127.)

De nemcsak a felszíni közlekedés áll le, hanem a légi is „Ferihegy nem indít és nem fogad” (Térey 2015, 388.). „Tisztára a Hoth bolygó, komolyan, már csak / A birodalmi lépegetőket hiányolom, gondolta Kőnig Attila író, a budai Fácán vendéglő udvarán (Térey 2015, 200.).

A tél időbeni kiterjedése és időjárási profilja - a csapadék mellett - a másik meghatározó indikátora a Duna-medence éghajlati változásainak. Lehűlés idején a hideg és havas időjárás meghatározza a téli félév (októbertől márciusig) nagyobb részének környezeti állapotát. Térey János víziója megrendítően apokaliptikus (6. ábra):

Utoljára vetettek a magvetók.

Utoljára aratnak az aratók,

És ősszel lesz az utolsó szüret.

Aztán jön a vulkánkollektíva ajándéka,

A müsoron kívüli tél: (Térey 2015, 76. ) 
6. ábra: A tél említésének eloszlása Térey János A Legkisebb Jégkorszak címü verses regényének szövegében

The distribution of references to the winter in the text of the poem-novel of The Smallest Ice Age by János Térey

$\checkmark$ tél

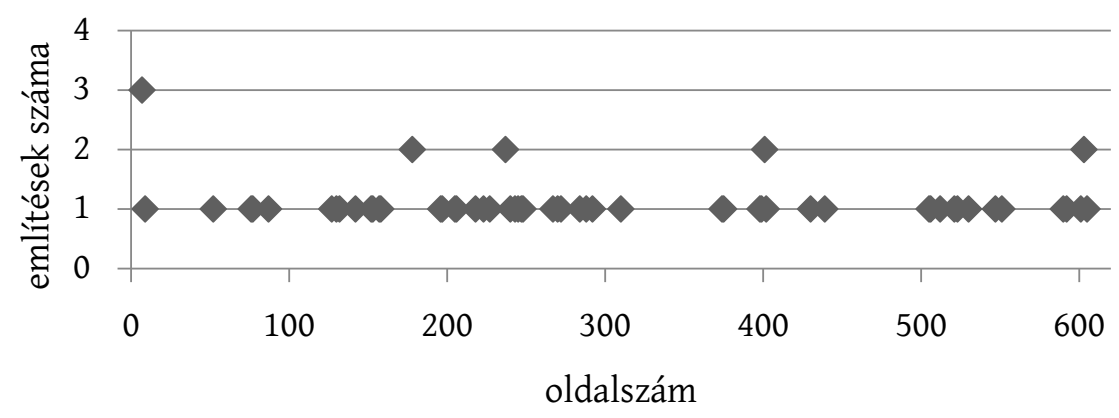

Ami történik, azonban nem előzmények nélküli a történeti emlékezet perspektívájában:

A Margit-sziget szabályosan körbefagyott,

Mint a középkor telein, amikor gyakran

Zárta körül a jég az akkor még a nyulakról elnevezett szigetet. (Térey 2015, 243.)

A tradicionális kor emberének eszközei és lehetőségei korlátozottabb, alkalmazkodóképessége azonban nagyságrendekkel jobb volt összevetve a jelenkorral. A legkisebb jégkorszak által előidézett éghajlati-környezeti változások a modern kor technikai eszközeinek a hatékonyságát nyesték vissza, amelyekre a modern ember élete, és ilyen formán a túlélése is alapozva van. A történet vége ugyanakkor nem egyértelmüen pesszimista (de mindenképpen optimistább, mint Madáché), hiszen:

A Legkisebb Jégkorszak második ősze ragyogó volt.

A hírek szerint a gabona szerte a kontinensen

Megfulladt a hó alatt. „Idén így jártunk,

De nem lesz mindig ugyanez, barátaim!

Fóleg a teleink bizonyulnak majd zordabbnak az eddigieknél",

Nyilatkozta egy uniós agrárbiztos.

Nem fagytak el a szölöfürtök a tökén;

Legalábbis nem mindenhol. (Térey 2015, 601.)

Reményeim szerint sikerült bizonyítanom, hogy Térey János verses regényében a természeti környezet nem közömbös díszlet az események hátterében, hanem a cselekmény irányát meghatározó szereplő. Ilyen módon A Legkisebb Jégkorszak tekinthető a modern magyar környezeti irodalom első, remélhetően úttörő regényének. Amennyiben Térey János úgy határoz, hogy megírja az Egy kicsit nagyobb jégkorszak, mint az előző munkacímű regényét, ezúton szeretném jelezni, hogy a téma elkötelezett szakértője vagyok. 


\section{Jegyzetek}

1 A hruscsovi korszak olvadása nyomán a szovjet újságíró-társadalomban összegyűlt az a kritikus tömeg, hogy a szovjet médiában megjelenjenek a rendszert óvatosan bíráló nézetek, amire a környezeti konfliktusok kérdése különösen alkalmas volt. A környezetvédelem szakmai jellege a cenzúrával szemben is védelmet jelentett, hiszen a „kommunista attitüd” részének tekintették a természeti értékek megőrzésére való törekvést. Igen fontos volt a szovjet írók szerepe a környezetvédelem közbeszédének alakításában. Leonyid Leonov a hruscsovi olvadás idején írta az Orosz erdő című regényét. Valentyin Raszputyin már a Brezsnyev-érában jelentette meg az Isten veled, Matyora című regényét, amelyben a szerző egy folyó szigetén épült város lakóinak sikertelen erőfeszítéseiről ír, akiknek a települése egy vízi erőmủ építése során pusztul el.

Egy rövid áttekintés az amerikai környezeti gondolkodás evolúciójáról magyar nyelven: Rácz (2006).

3 Az ökológia tudományterületét elsőként Ernst Haeckel határozta meg 1866-ban. Haeckel az ökológiai elnevezést két görög szó összeillesztésével hozta létre, amelyek az oikosz (lakóhely) és a logosz (tudomány) voltak. Juhász-Nagy Pál (1986) szellemes meghatározása szerint az ökológia azzal foglalkozik, hogy miért nem élhetnek az élőlények bárhol, bármikor, bármekkora számban a Földön.

4 Cheryll Burgess Glotfelty volt az első, aki elfogadtatta az amerikai akadémiai-egyetemi világgal a környezeti irodalom létjogosultságát, és ugyancsak elsőként kapott egyetemi tanári státuszt mint „Professor of Literature and Environment” a Nevadai Egyetemen. Cheryll Burgess Glotfelty elérhetősége és életrajza a következő webcímen található: www.unr.edu/ english/people/cheryll-glotfelty.

5 A regény lapjait beszkenneltem, a szövegen karakterfelismerő programot futtattam le. Mivel nem az eredeti gépiratot használtam, ezért lehetséges, hogy néhány kifejezést nem fedeztem fel, és a valós említésszám az általam kigyűjtöttnél magasabb, de jelentős eltérés nagy valószínűség szerint nincs.

6 A globális léptékű lehűlés egyik lehetséges oka a vulkántevékenység, mivel a kitörések nyomán jelentős mennyiségű kén-dioxid és aeroszol kerül be a felső légkörbe. A kitörés nagyságától függően a vulkáni fátyol évekig leárnyékolhatja a Földet, és ezzel párhuzamosan megemeli a sztratoszféra hőmérsékletét, módosítva a felső légkörben végbemenő folyamatokat. Ugyanakkor a vulkánkitörések csak rövidebb távon képesek éghajlati változásokat előidézni. Néhány év, legfeljebb egy évtized nyomán a vulkáni por és hamu kiülepszik a légkörből, s ha nem kap utánpótlást, akkor megszűnik az éghajlatmódosító hatás.

7 A Balaton-felvidék vulkánjainak aktív időszaka 3 millió éve lezárult, az Északi-középhegység vulkánjai (Börzsöny, Cserhát, Mátra és Zempléni-hegység) 15 millió évesek, ám a székelyföldi Hargita 30 ezer éve még minden valószínűség szerint aktív volt (minderről részletesen: Harangi et al. 2016).

8 A Duna-befagyásokról részletesen: Rácz (2014). A Duna és az Adria befagyásáról egyaránt közöl forrásrészleteket Réthly Antal mindhárom forrásgyüjteménye (Réthly 1963, 1970, 1998).

9 A hőmérsékleti szélső értékekről lehet tájékozódni az Országos Meteorológiai Szolgálat honlapján: http://www.met.hu/eghajlat/magyarorszag_eghajlata/homersekleti_szelsoertekek/ Magyarorszag/index.php és a Wikipédián: hu.wikipedia.org/wiki/Magyarország_ hőmérsékleti_rekordjainak_listája.

10 A vaddisznó a magyar (környezet)történeti hagyományban igen ellentmondásos megítélés alá esik. Ökológiai szempontból a vaddisznók a magyarországi természetes fauna azon túlélői, amelyek viszonylag sikeresen alkalmazkodtak életterük folyamatos csökkenéséhez. Ez a viszonylagos siker jelentékeny mértékben annak volt köszönhető, hogy a háziasított sertések okán történetileg be- és kijárásuk volt az emberek világába, az antroposzférába. A tradicionális világban a határban legelő kondához rendre odacsapódtak a vaddisznók és árnyalták a háziasított sertések genetikai állományát. Ráadásul a vaddisznók közül némelyek spontán módon háziasították magukat, és annak minden kockázatával identitást váltottak. A magyar történeti ikonográfiában azonban a vaddisznó alattomos gyilkosként is szerepet kapott, aki Imre herceg és Zrínyi Miklós életét kioltotta. 


\section{Irodalom}

Bencsik O. (2015): Magyar „provokatív fehér”: társadalmi jelenségek időjárási jelentésekkel magyarázva. http://tiszatajonline.hu/?p=87413 (Letöltés: 2017. május 7.)

Carson, R. (1994): Néma tavasz. Katalizátor Kiadó, Budapest

Földényi F. L. (2015): Befagyott lelkek. Magyar Narancs, 43. http://magyarnarancs.hu/konyv/ befagyott-lelkek-96914/ (Letöltés: 2017. május 7.)

Glotfelty, C., Fromm, H. (1996): The ecocriticism reader: Landmarks in literary ecology. University of Georgia Press, Athens

Harangi Sz., Lukács R., Schmitt A.K., Dunkl I., Molnár K., Kiss B., Seghedi I., Novothny Á., Molnár M. (2016): Constraints on the timing of quaternary volcanism and duration of magma residence at Ciomadul volcano, East-Central Europe, from combined U-Th/He and U-Th zircon geochronology. Journal of Volcanology and Geothermal Research, 301., 66-80. http://doi.org/f7k8bj

Juhász-Nagy P. (1986): Egy operativ ökológia hiánya, szükséglete és feladatai. Akadémiai Kiadó, Budapest

Lászlóffy W. (1934): Folyó jégviszonyai különös tekintettel a magyar Dunára. Vízügyi Közlemények, 3., $1-127$.

Madách I. (1971): Az ember tragédiája. Szépirodalmi Könyvkiadó, Budapest

Marsh, G. P. (1965): Man and nature. Or physical geography as modified by human actions. The Harvard University Press, Cambridge

Pogrányi P. (2016): Térey János: A Legkisebb Jégkorszak. Tiszatáj, 11. http://tiszatajonline.hu/?p=103863 (Letöltés: 2017. május 7.)

Rácz L. (2006): Az amerikai környezettörténeti kutatás genealógiája. In: Kiss A., Mezősi G., Sümeghy Z. (szerk.): Táj, környezet és társadalom: ünnepi tanulmányok Keveiné Bárány Ilona professzor asszony tiszteletére. SZTE Éghajlattani és Tájföldrajzi Tanszék, SZTE Természeti Földrajzi és Geoinformatikai Tanszék, Szeged, 581-592.

Rácz L. (2014): A Duna jégjárása és a pest-budai hajóhíd. In: Horváth G. K. (szerk.): Viz és társadalom Magyarországon a középkortól a XX. század végéig. Balassi Kiadó, Budapest, 247-282.

Rácz L. (2016): Mi a kis jégkorszak? Történeti Földrajzi Közlemények, 4., 15-46.

Radnóti S. (2015): Most tél van és csend és hó és... http://www.revizoronline.com/hu/cikk/5812/tereyjanos-a-legkisebb-jegkorszak/ (Letöltés: 2017. május 7.)

Réthly A. (1963): Időjárási események és elemi csapások Magyarországon 1701-ig. Akadémiai Kiadó, Budapest

Réthly A. (1970): Időjárási események és elemi csapások Magyarországon 1701-1800-ig. Akadémiai Kiadó, Budapest

Réthly A. (1998): Időjárási események és elemi csapások Magyarországon 1801-1900-ig. 1-2. kötet. OMSZ, Budapest

Térey J. (2015): A Legkisebb Jégkorszak. Jelenkor Kiadó, Budapest

Tőry K. (1952): A Duna és szabályozása. Akadémiai Kiadó, Budapest

Varga M. (2016): Jégkorszak Székelyföldön. https://www.irodalmijelen.hu/2016-apr-19-1553/ jegkorszak-szekelyfoldon (Letöltés: 2017. május 7.)

Zsolnai Gy. (2016): Térey János: A Legkisebb Jégkorszak. http://www.kortarsonline.hu/archivum/2016/01/ terey-zsolnai.html (Letöltés: 2017. május 7.) 